Utah State University

DigitalCommons@USU

$5-1-2019$

\title{
Antipredator Mechanisms of Post-Metamorphic Anurans: A Global Database and Classification System
}

\author{
Rodrigo B. Ferreira \\ Utah State University \\ Ricardo Lourenço-de-Moraes \\ Universidade Estadual de Maringá \\ Cássio Zocca \\ Universidade Vila Velha \\ Charles Duca \\ Universidade Vila Velha \\ Karen H. Beard \\ Utah State University \\ Edmund D. Brodie Jr. \\ Utah State University \\ Follow this and additional works at: https://digitalcommons.usu.edu/eco_pubs \\ Part of the Ecology and Evolutionary Biology Commons
}

\section{Recommended Citation}

Ferreira, R.B., Lourenço-de-Moraes, R., Zocca, C. et al. Behav Ecol Sociobiol (2019) 73: 69. https://doi.org/ 10.1007/s00265-019-2680-1

This Article is brought to you for free and open access by the Ecology Center at DigitalCommons@USU. It has been accepted for inclusion in Ecology Center Publications by an authorized administrator of DigitalCommons@USU.

For more information, please contact

digitalcommons@usu.edu.

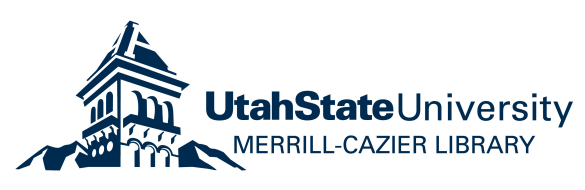




\section{Antipredator mechanisms of post-metamorphic anurans: a global database and 2 classification system \\ 3}

4 Rodrigo B. Ferreira ${ }^{1,2^{*}}$, Ricardo Lourenço-de-Moraes ${ }^{3}$, Cássio Zocca ${ }^{1}$, Charles Duca ${ }^{1}$, Karen H.

5 Beard $^{2}$, Edmund D. Brodie Jr. ${ }^{4}$

6

7 ' Programa de Pós-Graduação em Ecologia de Ecossistemas, Universidade Vila Velha, Vila Velha, ES, 8 Brazil

$9 \quad{ }^{2}$ Department of Wildland Resources and the Ecology Center, Utah State University, Logan, UT, United 10 States of America

$11{ }^{3}$ Programa de Pós-Graduação em Ecologia de Ambientes Aquáticos Continentais, Universidade Estadual 12 de Maringá, Maringá, PR, Brazil

$13 \quad{ }^{4}$ Department of Biology and the Ecology Center, Utah State University, Logan, UT, United States of 14 America

*Corresponding author: Rodrigo B. Ferreira, Laboratório de Ecologia da Herpetofauna Neotropical, Programa de Pós-Graduação em Ecologia de Ecossistemas, Universidade Vila Velha, Av. José Dantas. CEP: 29102-920 Vila Velha, ES, Brazil (E-mail: rodrigoecologia@yahoo.com.br; +55 27 99865-5395)

\section{Abstract}

A crucial step in any ethological study is to distinguish and classify the observed behavior into categories. The literature on anuran antipredator mechanisms is largely scattered and descriptive due to the opportunistic nature of the observations and the lack of a simple, widely accepted classification scheme. We propose an explanatory classification system of antipredator mechanisms for post-metamorphic anurans (i.e., juveniles and adults) based on a thorough review of the literature and observations made during fieldwork and in the laboratory since 1970. In addition, we provide a freely available global database on antipredator mechanisms of post-metamorphic anurans. The classification system is composed of 12 antipredator mechanisms and 28 variations distributed into three stages of defense (avoid detection, prevent attack, and counterattack). The database comprises 650 species and 39 families providing a unique opportunity to investigate ecological and evolutionary questions regarding antipredator mechanisms of anuran. We provide a general overview of geographic, taxonomic and phylogenetic patterns found in the database. Both our studies and that of our colleagues added 70 species 
to the database. The number of publications on antipredator mechanisms increased substantially after the year 2000. We hope to spark a renewed interest in antipredator mechanisms of post-metamorphic anurans to understand further the evolution of predator-prey interactions.

\section{Significance statement}

Predation is a phenomenon of great ecological and evolutionary significance. Hence, the study of antipredator mechanisms may provide some of the most fascinating answers to questions regarding species "struggle for existence". Based on extensive fieldwork, laboratory observations and a thorough literature survey, we propose a classification system of antipredator mechanisms for anurans, and provide a database of antipredator mechanisms elicited by frogs. We describe each mechanism, discuss the variations, and provide images for most antipredator mechanisms.

Running head: Antipredator mechanisms of anurans.

Keywords Amphibians, Anura, defense, defensive behavior, ethology, predator-prey.

\section{Acknowledgments}

We thank colleagues that helped on the field and on the database, provided data or photos and valuable 5 discussions (Alexander T. Mônico, Caio Miranda-Mendes, Carlly Brooke, Cecília Waichert, Daniel 2 Loebmann, Felipe S. Campos, Fernanda C. Lirio, Fernando Leal, Isabela A. M. Alves, João F. R. Tonini, 3 Michelly Gally, Priscila Gambale, Paulo Mello-Sampaio, Renan Oliveira, and Thiago Silva-Soares).

54 Mirco Solé for revising the manuscript. We thank anonimous reviewers for improving the text. 
57 A crucial step in any ethological study is to distinguish and classify observed behavior into separate categories (Janik 1999). Pattern recognition is the most common approach of classification by human observers because it is reproducible and communicable. Because of this, researchers often use images and a detailed description of the behavior to describe animal behavior (Barrett and Seeley 2015). Researchers have largely overlooked or superficially treated antipredator mechanisms in postmetamorphic anurans. The literature on anuran defensive behavior is largely descriptive due to the opportunistic nature of observations in the field and the lack of a classification scheme (Wells 2007). As result, there are scattered studies on the topic throughout the literature, often published as short notes and focused on single species. To date, there have been two reviews of anuran antipredator mechanisms (see Dodd 1976; Toledo et al. 2011). Dodd (1976) listed 22 types of defensive behavior and provided a bibliography list on the topic. Toledo et al. (2011) listed 30 types of defensive behavior and provided a brief description of each one. Despite the advances of these studies, they lack: i) a comprehensive and detailed scheme to classify antipredator mechanisms, ii) a compiled global-scale dataset, and iii) a general overview of geographic, phylogenetic and taxonomic patterns. A unified classification system and a global database of anuran antipredator mechanisms will facilitate and enhance studies focused on predator-prey interactions of anurans.

Studies of predator-prey interactions continue to be one of the most fascinating and important aspects of ecological research (Mukherjee and Heithaus 2013). Many studies have shown interactions between anurans and their predators, such as arthropods, including insects, spiders, and centipedes, and nearly all vertebrate groups from fish to mammals to birds (Toledo 1995; Zug et al. 2001). Thus, selective pressure driving the evolution of antipredator mechanisms in anurans is likely strong.

Predation is a phenomenon of great ecological and evolutionary significance. Hence, the study of antipredator mechanisms may provide answers to questions regarding species "struggle for existence" (Zug et al. 2001). Based on extensive fieldwork, laboratory observations, and a thorough literature survey, our goal is to: i) provide a freely-available global database with most records on antipredator mechanisms elicited by anurans, and ii) propose an explanatory classification system of antipredator mechanisms in post-metamorphic anurans. We describe each mechanism, discuss the variations, and provide images for 


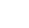

most antipredator mechanisms. In addition, we provide a general overview of geographic, taxonomic and evolutionary patterns found in the database.

\section{Material and Methods}

\section{Data compilation}

We compiled a global database of antipredator mechanisms for post-metamorphic anurans based on a literature survey, our own fieldwork, and consultation with colleagues. We conducted an extensive literature survey of antipredator mechanisms for post-metamorphic anurans in the following databases: Brill online books and journal, Google Scholar, Scientific Electronic Library Online (SciELO), Scopus, Taylor and Francis Library Online, and Web of Science. In all cases, we used the following keywords: antipredator mechanism, antipredator behavior, defensive behavior, and defensive strategy combined with either frog or anuran. We searched the major herpetological journals often used to publish on this topic (Amphibia-Reptilia, Journal of Herpetology, Herpetologica, Herpetological Review, and Herpetology Notes) and consulted original cross-references before adding them to the database.

We also used observations on antipredator mechanism from our fieldwork since 1970 at many locations in most zoogeographic regions (i.e., Australian, Afrotropical, Neotropical, Neartic, Palaeartic, and Oriental). We used focal animal sampling (Altmann 1974) and simulated predator attack by using finger-only stimuli and multiple stimuli (see Lourenço-de-Moraes et al. 2016). We tested anurans under both field and laboratory conditions. In addition, we have emailed colleagues requesting observations on antipredator mechanisms of anurans. The records of species without precise taxonomic identification at the species-level (i.e., aff., cf., and gr.) were removed from the database. Taxonomic classification follows Frost (2018).

\section{Classification criteria}

We adopted the term antipredator mechanism to include behavioral, morphological and physiological adaptations aiming to reduce predation success during predator-prey interactions. Some behaviors should 
113 not be considered antipredator mechanisms (Brodie Jr. et al. 1991), such as occupying microhabitat

114 refugee (e.g., burrow, crevice and dense vegetation), use of different foraging habitat (spatial avoidance),

115 or adjusting activity periods (temporal avoidance). These specific defense behaviors enhance the

116 survivorship of prey by reducing the probability that they will occupy the foraging microhabitat of

117 potential predators.

118 Because the assignment of antipredator mechanism is inherently a subjective process, we took

119 several steps to standardize the process:

120 1) All mechanisms were placed in one of three stages of defense (avoid detection, prevent attack, or

121 counterattack);

122 2) The mechanism should have the potential to be measured as reducing predation success in a situation

123 of predator-prey interaction (i.e., behaviors that only reduce injury (e.g., eye protection in Toledo et al.

124 2011) were not considered antipredator mechanisms);

125 3) Antipredator variations are specific adaptations within the mechanism;

126 4) All mechanisms and variations had to be observed in a minimum of three individuals consistently for 127 each genus; and

128 5) Individuals tested had to be observed by two observers to reduce misinterpretation of anuran antipredator display.

We found that many mechanisms listed in the literature had similar purposes and therefore should have been considered the same mechanism. Our goal was to assess each described antipredator mechanism carefully to determine whether the trait is a variation of a broader category of mechanism, the same mechanism that is known by another name, or a unique mechanism. The naming used in our classification system is based on the purpose of the antipredator mechanism. When there was more than one name assigned to a behavior, the most descriptive name was adopted.

\section{Reconstruction of ancestral states}

In order to provide a general overview on the evolution of the 12 proposed antipredator mechanisms, we reconstructed these characters in a phylogenetic tree. Further analyses and/or exhaustive discussion will be presented in a forthcoming manuscript. 

trimmed the tips to represent the 39 families for which we have data on antipredator mechanism. For this, we created a matrix of the 12 antipredator mechanisms coding presence (1) or absence (0) at the family level. We reconstructed the evolution of these antipredator mechanisms via parsimony using the "Trace Character History" function in the program Mesquite version 3.0 (Maddison and Maddison 2015).

\section{Data availability}

Freely available database is on Online Resource 1 . The references from the database are on Online Resource 2.

\section{Results}

We compiled a global database comprising 2953 records on antipredator mechanisms of 650 postmetamorphic anuran species within 180 genera and 39 families. Hylidae had the highest number of species $(\mathrm{N}=151 ; 23 \%)$ in the database. Out of 650 species, $147(23 \%)$ were recorded from more than one data source (i.e., literature, colleagues or fieldwork). From exclusively one data source, literature provided data for 433 species (67\%), colleagues for $40(6 \%)$ species, and our fieldwork for $30(5 \%)$ species. 2000 (Fig. 1). The records from the Neotropical region represent $462(71 \%)$ species, followed by $56(9 \%)$ species from Australian region, 46 (7\%) species from Neartic region, 42 (6\%) species from Oriental region, 30 (5\%) species from Afrotropical region, and 17 (2\%) species from Palaeartic region. Three (0.5\%) species (Bombina maxima, Hypopachus variolosus and Lithobates catesbeianus) were recorded from more than one zoogeographic region. The database has records from 52 countries, of which Brazil has the most records $(\mathrm{N}=368$ species; $57 \%)$, followed by Australia $(\mathrm{N}=51$ species; $8 \%)$ and the United States $(\mathrm{N}=41$ species; $6 \%)$. 
171 From our database and literature review, we present a classification system of antipredator mechanisms of

172 post-metamorphic anurans (Table 1). This classification system is composed of 12 antipredator

173 mechanisms and their respective variations placed in three phases of defense (avoid detection, prevent

174 attack, and counterattack).

175

176 Defense phase: Avoid detection

177

178 This phase of predator-prey interaction consist of the prey avoiding detection by a predator. This phase

179 occurs when the predator and prey share the same microhabitat and the prey is within the perceptual field

180 of the predator (see Brodie Jr. et al. 1991). This phase of avoid detection includes the following

181 antipredator mechanisms: camouflage, immobility, and interrupt calling (described below).

182

\section{Camouflage}

184 Camouflage includes several prey adaptations (e.g., behavior, coloration, and structures) that avoid 185 detection by the predator by becoming difficult to see (i.e., crypsis) or by disguise (i.e., mimesis). Other terms have been commonly used, such as cryptic coloration (e.g., Cott 1940; Merilaita et al. 1999; Merilaita 2003), obliterative coloration (Thayer 1909), concealing coloration (Cott 1940), or crypsis (e.g., Edmunds 1974). Camouflage is symplesiomorphic in Anura (Fig. 2a).

1a. Background matching is the prey's visual resemblance to its current or most commonly used substrate (i.e., homochromy or imitation of reflected light). It is also called cryptic resemblance (Cott 1940) and crypsis (sensu Endler 1978). Some hylids have dorsal color patterns resembling lichen-covered tree bark that resemble moss or lichens (Fig. 3a). Most leaf-litter anurans have brown as the dominant dorsal colors to resemble leaf litter (Fig. 3b). Many anurans that escape from predators by diving into water bodies have dark coloration and mottled patterns to resemble algae-covered, sandy or muddy substrates (Wells 2007). Some anurans choose a microhabitat to increase similarity to a background, or choose a background with greater scene complexity where predator's searching is difficult (i.e., substrate selection) (Webster et al. 2011; Caro 2014). Some anurans (e.g., Centrolenella and Vitreorana) have pronounced reflectance in the infrared wavelengths and partially transparent venter (i.e., transparency) to 

match the background by actively changing their skin patterns and colors using special chromatophore cells (i.e., color polyphenism). The color change may occur instantaneously, or may take a few minutes or even weeks to happen. It has been observed in anurans as changes in reflectance, resulting in lightening or darkening of the skin (King et al. 1994). In fact, most hylids are darker at night than during the day. For example, the hylid Boana albopunctata has been observed changing color from yellowish at night to light beige at daylight (RBF et al. pers. obs.). the skin to disrupt the outline of the animal (Zug et al. 2001). It is the continuity of surface, bounded by a specific contour or outline, which chiefly enables the recognition of objects, thus preventing a match with a predator's search image (Merilaita and Lind 2005). Among the morphological modifications related to this mechanism are supraciliary processes, scalloped fringes along the outer margins of the limbs, appendages, and a variety of warts and tubercles. For example, eliminating shadow is used by some hylids that have flange to help hide the shadow and a pale fringe breaks up and averages out any shadow that remains. Behaviorally an anuran presses itself against the substrate to flatten the body. Eliminating shadow is probably more effective to avoid predation for diurnal-active anurans or those resting during daylight. There is a substantial amount of evidence that risk of detection correlates with the degree of resemblance between prey and background (e.g., Turner 1961; Sandoval 1994; Nystrand and Granström 1997; Merilaita et al. 2001; Merilaita and Lind 2005). imitation of morphology) or natural movement (i.e., homokinemy or imitation of movement). This adaptation is called masquerade or mimesis and plays important roles in visual recognition. Masquerade is considered deceptive because the prey resembles something else, which is of no special interest to the predator. For example, anurans use coloration, spines, appendages, and a variety of warts and tubercles to resemble stones, bird dropping, or fallen leaves (e.g., Odontophrynus americanus, Fig. 3d). Also, anurans imitate natural movement, such as Phasmahyla exilis that sway slightly when walking on a branch resembling the wind movement (RBF pers. obs.). Background matching was displayed by $585(90 \%)$ species within $171(95 \%)$ genera and 39 
were the most frequently represented genera. Hylidae ( $N=143$ species; 24\%) and Bufonidae ( $N=91$ species; $51 \%$ ) were the most frequently represented families displaying background matching.

1b. Disruptive coloration is the use of contrasting markings to break up the appearance of body form (Fig. 4a, b). The idea behind disruptive coloration is to make the detection of edges and boundaries more difficult. Many anurans use disruptive coloration by having light dorsal stripes, irregular blotches or spots, and dark eye lines or ocular marks (Wells 2007).

Disruptive coloration was displayed by $32(5 \%)$ species within $14(8 \%)$ genera and eight (21\%) families from three zoogeographic regions (Afrotropical, Neartic and Neotropical). Allobates, Ameerega, Dendropsophus, Boana and Kassina (N= 4 species each; 12.5\%) were the most frequently represented genera displaying disruptive coloration. Dendrobatidae ( $\mathrm{N}=9$ species; $28 \%)$ and Hylidae $(\mathrm{N}=8$ species; $25 \%$ ) were the most frequently represented families displaying disruptive coloration.

\section{Immobility}

The behavior of remaining immobile during a predator's approach is a widespread antipredator mechanism in anurans to avoid detection by a visually oriented predator. Anurans can detect the presence of a predator through visual, acoustic or substrate vibration signals. Once the threat is detected, anurans become immobile and may have heightened alertness and prepare to jump away (Fig. 5a), flatten themselves against the ground to use the cryptic dorsal coloration (Fig. 5b), or remain still. Many species that show morphological crypsis often move slowly or rest quietly for considerable portions of foraging time (Caro 2014). This adaptation is possibly a precursor to other displays. Most predators attack only moving prey and immobile prey do not fit that search image (Brodie Jr. 1977; Toledo et al. 1995). But if the anuran is detected, immobility might reduce the likelihood of further predator attack or reduce the intensity of attack (Nishiumi and Mori 2015, 2016). Additionally, immobility may cause less harm to the anuran than would struggle within the predator's grip (Sazima 1974). Toledo et al. (2011) observed that a predatory snake did not prey upon two immobile hylid species. Also a domestic cat did not detect an immobile anuran (RLM pers. obs.).

Immobility was displayed by 159 (24\%) species within 73 (41\%) genera and $22(56 \%)$ families of anurans from all zoogeographic regions. Rhinella, Boana (N=10 species each; 6\%) and Dendropsophus 

species; 33\%) and Bufonidae ( $\mathrm{N}=24$ species; $15 \%)$ were the most frequently represented families displaying immobility. Immobility is symplesiomorphic in Anura (Fig. 2b).

261

\section{Interrupt calling}

The interruption of vocalization at predator approach aims to avoid giving predators a cue to anuran location. Also, anurans in chorus can stop calling after emission of a distress or alarm call by a conspecific (e.g., Gastrotheca megacephala, see Lourenço-de-Moraes et al. 2016). The interruption of calling was displayed by $10(2 \%)$ species within $10(6 \%)$ genera and five

267 (13\%) families of anurans from two zoogeographic regions (Neartic and Neotropical). All genera were represented by only one species. Hylidae ( $\mathrm{N}=5$ species; $50 \%)$ was the most frequently represented family displaying interruption of calling. Interruption of calling is homoplastic, having evolved independently in Odontophrynidae, Hemiphractidae, Leptodactylidae and Hylidae (Fig. 2c).

\section{Defense phase: Preventing attack}

The antipredator mechanisms of this phase are responsible for warning predators to keep away and avoid direct contact. In this phase, the anuran is within capture distance of the predator. This phase includes the antipredator mechanisms: aposematism, charge, posture, escape, and warning sound (described below).

\section{Aposematism}

278 The display of bright coloration (often bright red, blue, orange, yellow), hypertrophied glands, and eyeshaped spots on the dorsum, axila, underside of the body, thighs or post-femoral region serve as deceptive signals to disorientate and confuse an attacking predator and/or warn predators of the presence of toxins or unpalatability. Aposematism varies in the color (type and intensity), shape (spot, blotch, ring), and body region. To be conspicuous, aposematism requires that the color patterns of prey species contrast with the prevailing background coloration (Siddiqi et al. 2004). Aposematic signals are beneficial for both the predator and prey, both of which avoid potential harm. It works for visually oriented predators, in which birds are assumed to be the main selective agent favoring evolution of aposematic patterns (Wells 
Anura with many apomorphies across families (Fig. 2d).

288

289

290

291

292

293

294

295

296

297

298

299

300

301

302

303

304

305

306

307

308

309

310

311

312

313

314

4a. Exposed aposematism occur in species that have aposematic color over the entire body (e.g., Atelopus, Brachycephalus and Mantella species) (Fig. 6a). Exposed aposematism was displayed by 37 (6\%) species within $14(8 \%)$ genera and eight (21\%) families of anurans from four zoogeographic regions (Afrotropical, Australian, Neotropical and Oriental). Brachycephalus (N=13 species; 35\%), Oophaga and Ranitomeya $(\mathrm{N}=4$ species each; $11 \%$ ) were the most frequently represented genera displaying exposed aposematism. Dendrobatidae ( $\mathrm{N}=16$ species; 43\%) and Brachycephalidae ( $\mathrm{N}=13$ species; $35 \%)$ were the most frequently represented families displaying exposed aposematism.

4b. Hidden aposematism occur in species that have aposematic color at the axila, underside of the body, tongue, thighs or post-femoral region. These species usually exhibit the hidden aposematic or deceptive coloration through escape or postures such as rear elevation, unken reflex, and death feigning. For example, a leptodactylid (Edalorhina perezi) and a miobatrachid (Uperoleia lithomoda) may show a pair of eyespots by lifting their hindparts (Fig. 6b, c). These species have large poison glands below the eyespots. Phyllomedusids (e.g., Phyllomedusa rohdei and P. burmeisteri) show bright coloration on the thighs when walking on tree branches (Fig. 6d). The hyperoliid Acanthixalus spinosus shows bright yellow tongue when displaying death feigning (Perret 1961).

Hidden aposematism was displayed by 244 (38\%) species within 92 (51\%) genera and 25 (64\%) families of anurans from all zoogeographic regions. Melanophryniscus $(\mathrm{N}=20$ species; 8\%), Boana $(\mathrm{N}=$ 17 species; 7\%) and Phyllomedusa (N=11 species; 5\%) were the most frequently represented genera displaying hidden aposematism. Hylidae ( $\mathrm{N}=56$ species; 23\%), Bufonidae ( $\mathrm{N}=35$ species; $14 \%)$ and Leptodactylidae ( $\mathrm{N}=26$ species; $11 \%$ ) were the most frequently represented families displaying hidden aposematism.

\section{Charge}

This mechanism is characterized by the anuran moving, mostly by jumping, toward the predator. The anuran's apparent threat may intimidate the predator (see Nishiumi and Mori 2015). Charge may precede 
biting or head butting the predator. Some leptodactylids (e.g., Leptodactylus labyrinthicus and L. latrans) charge the predator, but if the predator faces off, the anuran may jump away. Only large-body species (> $7 \mathrm{~cm}$ ) have been seen charging the predator (Toledo et al. 2011). Charging is often associated with biting and a defensive scream (i.e., warning sound).

Charge was displayed by eight (1\%) species within six (3\%) genera and five (13\%) families of anurans from the Neotropical region. Boana and Ceratophrys ( $\mathrm{N}=2$ species each; 25\%) were the most frequently represented genera displaying charge. Hylidae ( $N=3$ species; $38 \%)$ and Ceratophryidae $(\mathrm{N}=2$ species; 25\%) were the most frequently represented families displaying charge. Charge is homoplastic, emerging independently in Calyptocephalidae, Ceratophryidae, Odontophrynidae, Hemiphractidae and Hylidae (Fig. 2e).

\section{Posture}

A variety of postures is intended to intimidate predators by changing the anuran's body shape. Posture is symplesiomorphic in Anura (Fig. 2f).

6a. Body elevation is the extension of anterior or all limbs, lifting the anuran's body off the ground. Body elevation is a deceptive mechanism because it increases the anuran's apparent size and threat (Williams et al. 2000). It may be displayed by extension of front limbs (partial elevation, Fig. 7a) or all limbs (full elevation, Fig. 7b). It is often displayed in synergy with vocalizing and/or biting. Some species may do "push-ups" moving the body up and down (RBF et al. pers. obs.). Body elevation was displayed by 54 (8\%) species within $36(20 \%)$ genera and 21 (54\%) families of anurans from all zoogeographic regions. Leptodactylus and Uperoleia ( $\mathrm{N}=4$ species each; 7\%) were the most frequently represented genera displaying body elevation. Bufonidae ( $\mathrm{N}=9$ species; $17 \%)$, Microhylidae ( $\mathrm{N}=8$ species; $15 \%)$ and Leptodactylidae ( $\mathrm{N}=7$ species; $13 \%)$ were the most frequently represented families displaying body elevation.

6b. Body inflation is characterized by the anuran inflating itself (Fig. 8a, b). Several terms have been used to designate this behavior, such as lung inflation, inflation of the body, and puffing-up the body (see Wells 2007; Toledo et al. 2011; Ferrante et al. 2014). All these behaviors are synonymous and 
consist of filling the lungs with air. This deceptive posture makes gripping prey more difficult, it may fool the predator into deciding that the prey is too large to handle and ingest, or both (Caro 2014). Because the anuran displaying body inflation becomes larger, it is very likely that this behavior intimidates the predator.

This behavior may be displayed in many substrates such as on vegetation, on the ground, and floating in the water (Toledo et al. 2011). In one reported observation, body inflation was successful at preventing predation of a Rhinella marina floating on the water (Blair 1947). This author reported that a Kinosternum sp. (freshwater turtle) gave up predation attempts on Rhinella marina when its lungs were inflated. Some species inside cavities (e.g., burrows, bromeliads, crevices) may also inflate the body to avoid being extracted (Toledo et al. 2011; Ferreira et al. 2015).

Body inflation was displayed by 216 (33\%) species within 95 (53\%) genera and 30 (77\%) families of anurans from all zoogeographic regions. Rhinella $(\mathrm{N}=16$ species; $7 \%)$ and Leptodactylus $(\mathrm{N}=$ 12 species; $6 \%)$ were the most frequently represented genera displaying body inflation. Hylidae ( $\mathrm{N}=43$ species; 20\%), Bufonidae ( $\mathrm{N}=30$ species; 14\%) and Leptodactylidae ( $\mathrm{N}=23$ species; $11 \%)$ were the most frequently represented families displaying body inflation.

6c. Contraction is the contraction of the four limbs, arching of the body and is usually associated with the head ventrally flexed. The anuran may have either the dorsum (Fig. 9a) or the venter (Fig. 9b) pointing to the substrate. The eyes can remain either opened or closed. This behavior may be displayed during the approach of a potential predator, or immediately after the potential predator touches the anuran or even after the subjugation phase (Sazima 1974; Toledo et al. 2011). Contracting displays likely aim to facilitate the release of skin secretions, cause prey to be difficult to swallow, or create the resemblance of a dead organism. While contracting, most species remain motionless, protecting vital areas of the body and, consequently, avoid more serious wounds (Sazima 1974).

During contracting, most species release some sort of repellant skin secretion (i.e., adhesive, odoriferous and noxious). Toledo et al. (2011) mentioned that 20 out of 25 species (80\%) were toxic during their tests on anurans displaying contracting. Some species while contracting have been partially swallowed by snakes but were regurgitated after some time (Sazima 1974; Brodie Jr. and Tumbarello 1978; Toledo et al. 2011). Choi et al. (1999) experimentally demonstrated that the "crouch" of the ranid 

regions or on the tongue (Toledo et al. 2011). Some anurans on contracting also pull the chin toward the pectoral region (called chin-tucking, Toledo et al. 2011). Boana $(\mathrm{N}=17$ species; $11 \%)$ and Bufonidae $(\mathrm{N}=10$ species; $7 \%)$ were the most frequently represented genera displaying contraction. Hylidae ( $\mathrm{N}=48$ species; 32\%) and Bufonidae ( $\mathrm{N}=25$ species; 17\%) were the most frequently represented families displaying contraction. display in species of Bufonidae and Odontophrynidae (Fig. 10a). Some bromeliad-dwelling anurans for instance, Aparasphenodon brunoi (Fig. 10b) and Corythomantis greening, display the co-ossified head covered by noxious glands while blocking the bromeliad cup after disturbance by a predator inside a bromeliad (Jared et al. 2005; Mailho-Fontana et al. 2014). Some authors have referred to gland exposure as body tilting (Toledo et al. 2011) or phragmosis (Jared et al. 2005). of anurans from five zoogeographic regions (Afrotropical, Australian, Neartic, Neotropical and Palaeartic). Rhinella (N=11 species; 20\%) and Anaxyrus ( $=5$ species; 9\%) were the most frequently represented genera displaying gland exposure. Bufonidae ( $\mathrm{N}=20$ species; 36\%), Hylidae and Odontophrynidae ( $\mathrm{N}=7$ species each; 13\%) were the most frequently represented families displaying gland exposure. antipredator mechanism aims to show aposematic coloration, facilitate the spread of skin secretion or feign injury. Also, the anuran may twist onto its back, throwing its limb across the body. 

2003). families of anurans from four zoogeographic regions (Afrotropical, Neartic, Neotropical and Palaeartic). All genera were represented by only one species. Hylidae ( $\mathrm{N}=2$ species; $33 \%$ ) was the most frequently represented family displaying limbs interweave.

408

6f. Mouth gape is the opening of anuran's mouth toward the predator (Fig. 12a, b). It may be displayed once or continuously by a prey. This behavior may be interpreted as a warning signal to the would-be predator and an attempt to intimate and avoid predation. with defensive vocalization and biting (Toledo et al. 2011; Lourenço-de-Moraes et al. 2016; Figueiredo et al. 2017). However, other species displaying mouth gaping did not emit defensive vocalization nor bite, for example Cycloramphus acangatan and Adelophryne glandulata (Lourenço-de-Moraes et al. 2012, 2014b). Some species have contrasting colors of the mouth lining, tongue and/or lower jaws in comparison to their body, which may be an aposematic display and influence predation avoidance (Duellman and Trueb 1994; Wells 2007). Miniature species (e.g., Brachycephalus spp, Adelophryne spp, Pseudopalodicola spp.) may use this mechanism to confuse predatory invertebrates, such as arachnids (e.g., Lourenço-de-Moraes and Pertel 2011). anurans from five zoogeographic regions (Afrotropical, Australian, Neartic, Neotropical and Oriental). Boana $(\mathrm{N}=8$ species; $13 \%)$ and Leptodactylus $(\mathrm{N}=5$ species; $8 \%)$ were the most frequently represented genera displaying mouth gape. Hylidae $(\mathrm{N}=17$ species; $28 \%)$, Hemiphractidae $(\mathrm{N}=7$ species; $12 \%)$ and Leptodactylidae ( $\mathrm{N}=6$ species; $10 \%$ ) were the most frequently represented families displaying mouth

6g. Rear elevation is the elevation of the posterior hind parts by leg extension. The degree of leg extension varies from low intensity (partially stretched, Fig. 13a) to high intensity (totally stretched, Fig. 13b). Another variation involves the position of the posterior limbs. During rear elevation, anurans may 
display aposematism by showing bright colorations, hypertrophied glands, eye-shaped spots on the axila, groin, underside of the body, thighs or post-femoral region (Sazima and Caramaschi 1986; Toledo and Jared 1995). For example, Physalaemus anurans have eyespot-like toxic glands on their lateral skin and elevate the body to display it when alarmed (Lenzi-Mattos et al. 2005; Fig. 13a). Some species have neither aposematic coloration nor odoriferous skin secretion. of anurans from all zoogeographic regions. Ranoidea $(\mathrm{N}=9$ species; $13 \%)$. Uperoleia $(\mathrm{N}=8$ species; $11 \%)$ and Limnodynastes ( $\mathrm{N}=4$ species; $6 \%$ ) were the most frequently represented genera displaying rear elevation. Myobatrachidae ( $\mathrm{N}=13$ species; 18\%), Pelodryadidae and Microhylidae ( $\mathrm{N}=10$ species; $14 \%)$ were the most frequently represented families displaying rear elevation. extension may be full or partial. It presumably aims to create a resemblance to a dead leaf or makes it difficult to be swallowed. Anurans display this posture after being touched by the predator. Stretching limbs posture is displayed by species of different clades, but this behavior is only known in leaf-litter anurans (Mângia and Santana 2013). It seems effective in avoiding detection by avian predators that forage on leaf litter (Sazima 1978). families of anurans from four zoogeographic regions (Afrotropical, Neartic, Neotropical and Oriental). Proceratophrys ( $\mathrm{N}=7$ species; 18\%), Dendrophryniscus and Rhinella (N=3 species; 8\%) were the most

451 frequently represented genera displaying stretching limbs. Microhylidae ( $N=11$ species; 28\%), Odontophrynidae ( $\mathrm{N}=9$ species; $23 \%)$ and Bufonidae ( $\mathrm{N}=7$ species; $18 \%)$ were the most frequently represented families displaying stretching limbs.

6i. Death feigning is when the fore and hind limbs are loose, and usually the dorsum is on the substrate (Fig. 15a, b). It is probably a mechanism to resemble a dead organism. Death feigning is also a strategy used by some species to show bright coloration on the exposed venter or members, which serve as an aposematic cue to predators (Brodie 1977). Death feigning is often displayed after the anuran has jumped away from the observer or was handled by the observer (Toledo et al. 2011). In general, 
individuals can remain immobile with the venter up for up to five minutes, and then actively flip to the normal position (i.e., dorsum up) and jump away. Death feigning is often used in synergy with odoriferous secretions that resemble a plant-like odor.

In cases of disturbance, some species may get flipped by the predator with the venter up to further increase the resemblance of a dead organism (Duellman and Trueb 1994; Toledo et al. 2011). Acanthixalus spinosus, Odontophrynus americanus and $O$. lavillai have been reported sticking the tongue out of the mouth (i.e., tongue-protrusion) while displaying death feigning (Perret 1961; Borteiro et al. 2018). Some species may actively flip onto the back and remain immobile in death feigning (i.e., flipping-onto the back; Toledo et al. 2011).

Death feigning was displayed by 203 (31\%) species within 79 (44\%) genera and $25(64 \%)$ families of anurans from all zoogeographic regions. Leptodactylus $(\mathrm{N}=14$ species; 7\%), followed by Dendropsophus and Boana $(\mathrm{N}=11$ species each; $5 \%)$ were the most frequently represented genera displaying death feigning. Hylidae ( $\mathrm{N}=53$ species; 26\%), Leptodactylidae $(\mathrm{N}=37$ species; $18 \%)$ and Bufonidae ( $\mathrm{N}=27$ species; 13\%) were the most frequently represented families displaying death feigning.

6j. Unken reflex is characterized by the body convexly arched and palms lifted and twisted off the substrate. This posture usually exhibits bright coloration on the ventral or palm regions. An anuran in unken reflex may be difficult for a predator to swallow. The bright coloration and distinctive posture displaying the ventral coloration are cues that are associated with noxiousness by predators (Duellman and Trueb 1994).

Unken reflex seems more displayed by species that have concentrations of granular glands widely distributed on the body and bright coloration on the ventral surfaces. Some species may show only the venter portion of the limbs, called partial unken reflex (e.g., Dendrophryniscus boulengeri, Fig. 16a) (Proceratophrys avelinoi, Lourenço-de-Moraes and Lourenço-de-Moraes 2012; Zachaenus carvalhoi, Zocca et al. 2014). Species with aposematic venters may show the palms of all limbs (i.e., full unken reflex; e.g., Bombina variegata, Fig. 16b). Also, some species do not present conspicuous coloration (e.g., Smilisca fodiens, Firschein 1951) (juveniles of Bombina spp., Löhner 1919). Leptobrachium smithi may elevate the head about $90^{\circ}$ from the ground (i.e., head-up sharp bend, Toledo et al. 2011), which functions like the unken reflex. 

represented families displaying unken reflex.

494

\section{Escape}

Escape includes behaviors displayed upon detection and approach of the predator to avoid further approach or direct contact. Escape depends on the locomotor capabilities of the species. Escape is symplesiomorphic in Anura (Fig. 2g).

7a. Climb is mostly displayed by arboreal species that climb higher to escape from predators that are coming from below.

Climb was displayed by $10(2 \%)$ species within six (3\%) genera and two (5\%) families of anurans from two zoogeographic regions (Neartic and Neotropical). Dryophytes ( $\mathrm{N}=3$ species; $30 \%)$, Pseudacris and Trachycephalus (N=2 species each; 20\%) were the most frequently represented genera displaying climb. Hylidae ( $N=9$ species; $90 \%)$ and Bufonidae ( $N=1$ species; 10\%) were the most frequently represented families displaying climb. another substrate. In addition to escape from predation, gliding is also used for anurans to descend to reproductive sites (McCay 2001). Gliding anurans (e.g., Rhacophorus dennysi and R. nigropalmatus)

511 (Fig. 17a) have some morphological features such as enlarged, extensively webbed hands and feet or skin flaps on elbows and ankles (Emerson and Koehl 1990; McCay 2001). the only genera displaying glide. 
518 may dig down into the substrate to hide. Burrowing anurans look for refugia in crevices. Bromeligenous

519 anurans retreat down the bromeliad leaf and hide in the base of the axils (e.g., Ferreira et al. 2015). anurans from five zoogeographic regions (Afrotropical, Australian, Neartic, Neotropical and Oriental). Dendropsophus $(\mathrm{N}=5$ species; $8 \%)$, Anaxyrus and Ololygon $(\mathrm{N}=4$ species each; $7 \%)$ were the most frequently represented genera displaying hide. Hylidae ( $\mathrm{N}=21$ species; $34 \%)$ was the most frequently represented family displaying hide. effective at increasing distance from predators that depend on chemosensory cues for trailing prey (Duellman and Trueb 1994). environment. For example, some Eleutherodactylidae display a single, long leap and subsequent immobility with the anuran relying on the camouflage to avoid subsequent discovery (i.e., evade). It seems that there is a tendency for large species to display this behavior. Some small species (e.g., Eleutherodactylus planirostris and Adelophryne glandulata) display a series of quick, short, and multidirecional hops and subsequent immobility (i.e., flee). Jump away was displayed by 219 (34\%) species within 88 (49\%) genera and 25 (64\%) families of anurans from all zoogeographic regions. Dendropsophus (N=15 species; 7\%), Boana and

537 Leptodactylus $(\mathrm{N}=10$ species each; 5\%) were the most frequently represented genera displaying jump away. Hylidae ( $\mathrm{N}=72$ species; 33\%), Leptodactylidae ( $\mathrm{N}=23$ species; $11 \%)$ and Bufonidae $(\mathrm{N}=21$ species; $10 \%$ ) were the most frequently represented family-displaying jump away. called "balling" and "tumbling". It has been observed in few anuran species (e.g., Oreophrynella nigra, O. quelchii, and O. vasquezi; Garcia-París and Deban 1995) (Fig. 17b). Roll was displayed by three $(0.5 \%)$ species within one $(1 \%)$ genus and one $(3 \%)$ family of anurans from the Neotropical region. Oreophrynella (Bufonidae) was the only genus-displaying roll. 
547 7f. Swim is displayed mostly by anurans adapted to bodies of water (i.e., river, streams or

548 ponds). Normally these anurans have webbed toes to aid in swimming and can remain under water for

549 minutes.

$550 \quad$ Swim was displayed by $22(3 \%)$ species within $17(9 \%)$ genera and $10(26 \%)$ families of anurans

551 from five zoogeographic regions (Afrotropical, Australian, Neartic, Neotropical and Oriental). Lithobates

$552(\mathrm{~N}=5$ species; $23 \%)$ and Anaxyrus $(\mathrm{N}=2$ species; $9 \%)$ were the most frequently represented genera

553 displaying swim. Ranidae (N=6 species; 27\%) and Hylidae ( $\mathrm{N}=4$ species; $18 \%)$ were the most

554 frequently represented family-displaying swim.

555

556

8. Warning sound

557 Warning sound is emitted by anurans to threaten predators before apprehension (Toledo et al. 2015) and

558 also after the touch of potential predator. It aims to warn sound-oriented predators (e.g., birds and

559 mammals) about any risk offered by would-be prey. Anurans can emit different types of warning sound that may be related to the intensity of stress stimuli by predator (Lourenço-de-Moraes et al. 2016). Warning sound can be emitted through the mouth or nostril. Warning sound has been observed in

562 Gastrotheca megacephala and G. recava (Lourenço-de-Moraes et al. 2016), Rhinella crucifer and $R$. diptycha (RBF et al. pers. obs.). Warning sound was displayed by $26(4 \%)$ species within $16(9 \%)$ genera and $14(36 \%)$ families from four zoogeographic regions (Afrotropical, Australian, Neartic and Neotropical). Ranoidea $(\mathrm{N}=4$ species; 15\%), Rhinella and Lithobates $(\mathrm{N}=3$ species each; 12\%) were the most frequently represented genera displaying warning sound. Pelodryadidae $(\mathrm{N}=4$ species; $15 \%)$, Bufonidae and Ranidae $(\mathrm{N}=3$ species each; $12 \%$ ) were the most frequently represented families displaying warning sound. Warning sound is homoplastic in Anura (Fig. 2h).

\section{Defense phase: Counterattack}

572 This phase is characterized by antipredator mechanisms that are responses to apprehension by the 573 predator, and the prey tries to escape through physical contact or noise. This phase includes the 574 antipredator mechanism: cloacal discharge, secretion, aggression, and distress call (described below). 


\section{9. Cloacal discharge}

577 This is the extrusion of liquid or solid content through the cloaca. Liquid is the most common cloacal 578 discharge. Most species (e.g., Haddadus binotatus and Ischnocnema oea) normally discharge cloacal 579 liquid after being approached or apprehended by a predator. Also, some species lift up the cloaca, point it 580 toward the collectors, and release liquid content (e.g., Haddadus binotatus). Solid discharge was reported 581 for Anaxyrus terrestris seized by a snake (Marchisin and Anderson 1978), and Boana albopunctata,

582 Boana faber and Boana semilineata (RBF et al. pers. obs.) after disturbance by collector's finger.

583 Cloacal discharge was displayed by $71(11 \%)$ species within $33(18 \%)$ genera and $15(38 \%)$ families from 584 two zoogeographic regions (Neotropical and Oriental). Rhinella, Boana $(\mathrm{N}=10$ species each; 14\%) and 585 Leptodactylus ( $\mathrm{N}=7$ species; $10 \%)$ were the most frequently represented genera displaying cloacal 586 discharge. Hylidae ( $\mathrm{N}=28$ species; 39\%) and Bufonidae ( $\mathrm{N}=12$ species; $17 \%)$ were the most frequently 587 represented families displaying cloacal discharge. Cloacal discharge arised independently in Anura with 588 extensive homoplasy (Fig. 2i).

589

590

\section{Secretion}

591 Most amphibians use secretory products of cutaneous glands (e.g., granular, mucous or poison glands) as 592 antipredator mechanisms (Brizzi and Corti 2007). The glands produce many different compounds, such as 593 amines, bioactive peptides, alkaloids, and their various combinations. The result is the synthesis of 594 adhesive, odoriferous, slippery and poisonous substances, with specific toxicities. Secretion is 595 symplesiomorphic in Anura (Fig. 2j).

596

10a. Adhesive is the production and release of skin secretion that has adhesive effect. It has been reported as an effective mechanism to Dyscophus antongili, Trachycephalus spp. and Hyophryne histrio

599 by preventing predation because it may render the predator immobile and/or unable to feed (Evans and

600 Brodie 1994; Williams et al. 2000; Toledo et al. 2011). The adhesive secretion has been an effective 601 antipredator mechanism against small mammals and snakes. In an experiment, Evans and Brodie (1994) showed that anurans able to produce adhesive secretions survived the trials with snakes. 
604 families from five zoogeographic regions (Afrotropical, Australian, Neartic, Neotropical and Oriental).

605 Dendropsophus, Trachycephalus, Leptodactylus, Dyscophus and Notaden (N=2 species each; 9\%) were

606 the most frequently represented genera displaying adhesive secretion. Microhylidae ( $\mathrm{N}=9$ species; 39\%)

607 and Hylidae ( $\mathrm{N}=8$ species; $35 \%$ ) were the most frequently represented families displaying adhesive

608 secretion.

609

$61010 \mathrm{~b}$. Odoriferous is characterized by the production and secretion of odor through the skin or

611 mouth. Some species produce floral, leaf-like, or ammonia odors possibly deceiving the predator that a

612 larger danger is present (Smith et al. 2004). Williams et al. (2000) speculated that if predators learn that

613 an unpalatable prey is associated with a certain odor, they may avoid prey with that odor in the future,

614 even if the odor itself is benign. It is recognized that some snakes assess the palatability of the prey prior

615 to attack (Shine 1993). In our observations, most odors were benign to observers, but some odors (e.g.,

616 released by Itapotihyla langsdorffii and Leptodactylus labyrinthicus) caused unpleasant effects, such as

617 nasal congestion and sneezing. Many anurans released odors in synergy with immobility and some

618 defensive postures (e.g., death feigning).

619 Odoriferous secretion was displayed by 102 (16\%) species within $29(16 \%)$ genera and $14(36 \%)$

620 families from five zoogeographic regions (Afrotropical, Australian, Neartic, Neotropical and Palaeartic).

621 Bokermannohyla $(\mathrm{N}=17$ species; 17\%), Aplastodiscus $(\mathrm{N}=13$ species; 13\%), Dendropsophus $(\mathrm{N}=11$

622 species; $11 \%)$, were the most frequently represented genera displaying odoriferous secretion. Hylidae $(\mathrm{N}=$ 62363 species; $62 \%)$ and Pelodryadidae $(\mathrm{N}=12$ species; $12 \%)$ were the most frequently represented families

624 displaying odoriferous secretion.

625

626

627

628

629

630

631

10c. Slippery is the production and release of slippery secretions through skin glands. It has been successful against tactile predators because they reduce the likelihood of being seized (Toledo et al. 2011). Slippery secretions generally are produced by aquatic or semi-aquatic anurans (e.g., Leptodactylus and Lithobates) (Toledo et al. 2011).

Slippery secretion was displayed by $36(6 \%)$ species within $15(8 \%)$ genera and eight (21\%) families from three zoogeographic regions (Afrotropical, Australian and Neotropical). Litoria $(\mathrm{N}=8$ 
632

633

634

635

636

637

638

639

640

641

642

643

644

645

646

647

648

649

650

651

652

653

654

655

656

657

658

659

species; 22\%), Ranoidea $(\mathrm{N}=7$ species; $19 \%)$ and Boana $(\mathrm{N}=5$ species; $14 \%)$ were the most frequently represented genera displaying slippery secretion. Pelodryadidae $(\mathrm{N}=15$ species; $42 \%)$ and Hylidae $(\mathrm{N}=$ 13 species; $36 \%$ ) were the most frequently represented families displaying slippery secretion.

10d. Poisonous is the liberation of toxic substances through the skin. The secretion can be either passively or actively released (see Mailho-Fontana et al. 2014). Most species passively release secretions after being apprehended by a predator. Some species (e.g., Corythomantis greeningi and Aparasphenodon brunoi) have active release mechanisms through bony spines on the skull that pierce the skin in areas with concentrations of skin glands (Jared et al. 2015). Poisonous skin secretion is the main antipredatory strategy of anurans to avoid predation (Jared et al. 2015).

Skin secretion acts simultaneously with other antipredator mechanisms such as defensive postures and aposematic color patterns. Toledo et al. (2011) reported that $80 \%$ of the species displaying "contracting" also released skin secretions. Lourenço-de-Moraes et al. (2014a) reported Leptodactylus chaquensis displaying death feigning in synergy with noxious secretions. Many species displaying "body elevation" have aposematic colors warning the predator about its toxicity.

Poisonous secretion was displayed by 198 (30\%) species within 74 (41\%) genera and $25(64 \%)$ families from all zoogeographic regions. Rhinella ( $\mathrm{N}=19$ species; 10\%), Brachycephalus $(\mathrm{N}=13$ species; 7\%), Melanophryniscus and Leptodactylus ( $\mathrm{N}=11$ species each; 6\%) were the most frequently represented genera displaying poisonous secretion. Bufonidae $(\mathrm{N}=63$ species; $32 \%)$, Dendrobatidae $(\mathrm{N}=$ 23 species; 12\%) and Phyllomedusidae ( $\mathrm{N}=18$ species; 9\%) were the most frequently represented families displaying poisonous secretion.

\section{Aggression}

Aggression is the use of morphological or behavioral adaptations to interact directly with predators. Aggression involves attempts to injure or hurt the predator to get released after being apprehended. Agression is symplesiomorphic, but was not recorded in families such as Bombinatoridae and Leiopelmatidae (Fig. 2k). 
661 (Fig. 18a). It is suggested that this behavior is related to diet (i.e., consumption of vertebrates) and 662 parental care (i.e., defense of progeny) (Lourenço-de-Moraes et al. 2016; Figueiredo et al. 2017). Bite was displayed by $30(5 \%)$ species within $16(9 \%)$ genera and $12(31 \%)$ families from four zoogeographic regions (Afrotropical, Australian, Neotropical and Oriental). Cycloramphus ( $\mathrm{N}=5$ species; 17\%), Ceratophrys and Leptodactylus ( $\mathrm{N}=4$ species each; $13 \%)$ were the most frequently represented genera displaying bite. Hemiphractidae ( $N=6$ species; 20\%), Ceratophryidae and Cycloramphidae $(\mathrm{N}=5$ species each; 17\%) were the most frequently represented families displaying bite. parental care such as some leptodactylids (Toledo et al. 2011). Some species walk or jump toward the predator and if reached, the predator may either be bitten or butted by the anuran's head. Headbutt is a common behavior in most bufonids where the parotoid glands are butted into an attacking predator. Headbutt was displayed by $10(2 \%)$ species within eight (4\%) genera and six (15\%) families from three zoogeographic regions (Afrotropical, Neotropical and Oriental). Leptodactylus $(\mathrm{N}=3$ species; $30 \%$ ) was the most frequently represented genera displaying headbutt. Hylidae and Leptodactylidae (N= 3 species each; $30 \%$ ) were the most frequently represented families displaying headbutt.

677

11c. Kick is the act of using the limbs to kick or slap the predator. This behavior is very common and generally displayed in the counterattack phase. The captured anuran pushes the predator's face or hands, sometimes with vigorous kicks (e.g., Myersiella microps, Mônico et al. 2016). zoogeographic regions (Neartic, Neotropical, Oriental and Palaeartic). Ololygon ( $\mathrm{N}=7$ species; 13\%), Boana and Dendropsophus ( $\mathrm{N}=5$ species each; 9\%) were the most frequently represented genera displaying kick. Hylidae ( $\mathrm{N}=26$ species; 48\%), Bufonidae ( $\mathrm{N}=6$ species; $11 \%)$ and Leptodactylidae $(\mathrm{N}=$ 5 species; $9 \%$ ) were the most frequently represented families displaying kick. 
for some genera of African arthroleptids such as Astylosternus, Scotobleps and Trichobatrachus, which have erectile-bony claws that protrude through the skin on the ventral side (Blackburn et al. 2008). When males or females are grabbed, these anurans kick their legs and rake claws against one's skin (Boulenger 1902). It is hypothesized that phalanx and prepollex have evolved primarily for reproduction purposes, such as grasping the female during amplexus and intraspecific male-male interaction (Wells 2007). Puncture was displayed by $17(3 \%)$ species within eight (4\%) genera and four (10\%) families from three zoogeographic regions (Afrotropical, Neotropical and Oriental). Boana (N= 5 species; 29\%), Bokermannohyla $(\mathrm{N}=4$ species; $24 \%)$ and Leptodactylus $(\mathrm{N}=3$ species; $18 \%)$ were the most frequently represented genera displaying puncture. Hylidae $(\mathrm{N}=11$ species; $65 \%)$ and Leptodactylidae $(\mathrm{N}=4$ species; $24 \%$ ) were the most frequently represented families displaying puncture.

\section{Distress call}

Distress call is the emission of a vocalization during subjugation by predator (Toledo et al. 2015). It is intended to avoid predation by scaring the predator, and also to attract other potential predators (Brodie and Formanowicz 1981; Toledo et al. 2015).

Distress calls may be emitted during expiration, when disinflation of the lungs may produce a noise (Toledo et al. 2011). When handled by observer, distress calls were emitted by many species during our observations.

Distress call was displayed by $99(15 \%)$ species within 38 (21\%) genera and $17(44 \%)$ families from five zoogeographic regions (Afrotropical, Australian, Neartic, Neotropical and Oriental). Boana $(\mathrm{N}=$ 17 species; 17\%), Leptodactylus $(\mathrm{N}=13$ species; $13 \%)$ and Ranoidea $(\mathrm{N}=7$ species; 7\%) were the most frequently represented genera displaying distress call. Hylidae ( $N=36$ species; $36 \%)$, Leptodactylidae $(\mathrm{N}=15$ species; $15 \%)$ and Pelodryadidae $(\mathrm{N}=12$ species; $12 \%)$ were the most frequently represented families displaying distress call. It is homoplastic in Anura, arising independently (Fig. 21).

\section{Characterization of post-metamorphic antipredator mechanisms}


717 Regarding the phases of antipredator mechanisms, 620 (95\%) species exhibited "avoid detection", 585

718 (90\%) species exhibited “prevent attack”, and $404(62 \%)$ species exhibited “counterattack”. Individuals 719 of $466(72 \%)$ species displayed "posture" and 305 (47\%) species released "secretion". The mechanisms 720 "interrupt calling" ( $\mathrm{N}=10$ species; $2 \%)$ and "charge" $(\mathrm{N}=8$ species; $1 \%)$ were the rarest displayed.

721 Regarding "postures", the variations "body inflation" (N=216 species; 33\%) and "death feigning" $(\mathrm{N}=$

722 203 species; 31\%) were the most displayed. The postures "limbs interweave" ( $N=6$ species; $1 \%)$ was the rarest displayed. Regarding "secretion", "poisonous" substance was the most produced (N=198 species; $30 \%$ ), followed by "odoriferous" ( $N=102$ species; 16\%), "slippery" ( $N=36$ species; 6\%), and "adhesive" $(\mathrm{N}=23$ species; $4 \%)$ substances.

Regarding species, Boana faber, Odontophrynus americanus and Leptodactylus latrans displayed the highest mean number of antipredator mechanisms $(\mathrm{N}=10 ; \mathrm{N}=10 ; \mathrm{N}=8$, respectively) and many antipredator variations $(\mathrm{N}=16 ; \mathrm{N}=10 ; \mathrm{N}=13$, respectively). Regarding genera, Myersiella $($ mean $=$ 9) and Haddadus (mean= 8) had the highest mean number of antipredator mechanisms. Regarding families, Calyptocephalellidae $($ mean=6), Leiopelmatidae $($ mean= 5) and Dicroglossidae $(\operatorname{mean}=5)$ displayed the highest mean number of antipredator mechanisms.

\section{Discussion}

Our freely available global database provides a unique resource to facilitate the investigation of ecological and evolutionary questions regarding antipredator mechanisms in anuran, especially if combined with quantitative measurements of morphological and ecological traits. The remarkable work done by some researchers in the previous decades (e.g., C. Jared, C. Haddad, L.F. Toledo and collaborators) may explain the increase in the number of publications on antipredator mechanisms of anurans through time. Toledo et al. (2011) compiled their observations of anti-predatory mechanisms, and this probably influenced the substantial increase in the number of publications on this topic. Another explanation for the increase in published anuran antipredator mechanisms may be related to the emergence of journals specialized in natural history observations (e.g., Herpetology Notes and Herpetological Review). 
747 weigh parameters differently in their pattern recognition and thus come up with different categories. By

748 using several observers, this potential problem may be reduced and a measure of observer agreement

749 obtained. Because our level of agreement was high, this argues that disagreement among observers is not

750 inherently a huge issue, and one can assume that our classification system is reproducible by others.

751 Nevertheless, we may have missed some small parameter differences that might be relevant to the

752 animals, for example, those caused by our limited sense of smell. Consequently, while this classification

753 system provides a useful starting point for further discussion, the various mechanisms should not be

754 viewed as clearly differentiated grades of evolution or the final word on the diversity of defensive

755 behavior in anurans.

It is noteworthy that the three species that displayed the highest number of mechanisms (i.e., $B$.

757 faber, L. latrans, and O. americanus) have wide geographic distribution. This may suggest that

758 antipredator mechanisms are favored by selection. The various antipredator mechanisms displayed by

759 these frogs appear to interact and total protection may be greater than the sum of each of the behaviors

760 alone. It has been hypothesized in other taxa that the display of simultaneous mechanisms may be more

761 effective in transmitting signals to predators (Williams et al. 2000). This hypothesis remains to be tested

762 in anurans. In salamanders, the interaction of toxic skin secretions, aposematic coloration and postures is

763 important in predator avoidance (Johnson and Brodie 1975). It seems that an individual can switch

764 between mechanisms depending on the threat. For instance, we observed Gastrotheca megacephala and

765 G. recava emplying escalating antipredator mechanisms according to the degree of stress imposed by the

766 potential predator (see Lourenço-de-Moraes et al. 2016). Predation involves several phases such as locate,

767 identify, approach, subjugate, ingest, and digest prey (Mailho-Fontana et al. 2014). Therefore, the more

768 types of antipredator mechanisms a species can display, the more likely this species is to escape

769 predators.

770 Species that have many antipredator mechanisms may choose to display them simultaneously.

771 For instance, most mechanisms displayed by two species of Gastrotheca were displayed simultaneously

772 (Lourenço-de-Moraes et al. 2016). Gastrotheca recava displayed warning call simultaneously with body

773 inflation and mouth gaping (Lourenço-de-Moraes et al. 2016). It is noteworthy that the release of skin 
secretion and display of hidden aposematic colors is commonly associated with defensive postures such as body raising, contracting, and leg interweaving (Brodie et al. 1998; Lourenço-de-Moraes et al. 2014a). The reconstruction of the ancestral states of the antipredator mechanisms in the phylogenetic tree showed that most mechanisms are plesiomorphic in Anura. It is likely that the plesiomorphic mechanisms originated from the common ancestors of anurans and other amphibians (i.e., salamanders and caecilians). For example, many salamanders display camouflage, immobility, posture, escape and secretion. Many antipredator mechanisms arose independently across families suggesting extensive homoplasy in Anura. However, some of the apparently homoplastic antipredator mechanisms may be a consequence of the lack of observations on species displaying them. For example, distress call, warning sound and interrupting call are rarely reported in the literature and may be more widespread in anurans.

The remarkable convergent evolution in aposematic color pattern across species suggests mimicry is a common protective strategy in anurans. However, the lack of studies on the potential toxicity (or other defense) of most apparent mimic species prevents further generalization about mimicry in anurans. The few studied cases of Batesian mimicry in anurans show that mimics successfully deceive predators (Darst et al. 2006). For instance, in a Batesian mimicry system the non-toxic Allobates species successfully avoided predation by imitating the toxic Epipedobates species (Darst et al. 2006). In Dendrobatids the aposematism is a complex trait, which integrates evolution in diet (to which the defensive alkaloid is sequestered), physiology, morphology and behavior (see Santos and Cannatella 2011). Williams et al. (2000) showed that non-toxic Crinia species expose aposematic ventral coloration to possibly mimic the toxic Pseudophryne. Müllerian mimicry in anurans has been documented in congeners of Ranitomeya, Mantella, and Phyllobates (Toledo and Haddad 2009a). But it is not simple to distinguish real, nondeceitful homotypy from a possible phylogenetic influence because some closely related species may resemble one another due to a symplesiomorphic (i.e., sharing of an ancestral character, secretion) and not because of coloration convergence (homoplasy, aposematism).

The classification of antipredator mechanisms depicted in the present study should not be considered an immutable scheme but actually an evolving set of descriptions. We hope to spark renewed interest in antipredator mechanisms of post-metamorphic anurans to understand further the extent to which they are deployed by a given prey species must depend on the background on which it lives, the 
802

803

804

805

806

807

808

809

810

811

812

813

814

815

816

817

818

819

820

821

822

823

824

825

826

827

828

829

830

relation of prey morphology and defenses, the visual capabilities and behavior of the predator, its relative size compared to its predators, and even the defenses of sympatric prey species.

\section{Compliance with ethical standards}

\section{Funding}

We thank the Bromeligenous Project for logistical support that was sponsored by the Ecology Center at Utah State University (EC-USU), Dr. Dinesh and Kalpana Patel Fellowship, and Rufford Foundation.RBF thanks Utah State University, Coordenação de Aperfeiçoamento de Pessoal de Nível Superior - Brasil (CAPES, 0823/2015) and Conselho Nacional de Desenvolvimento Científico e Tecnológico - Brasil (CNPq, 231020/2013-9) for scholarships. RLM thanks CNPq (140710/2013-2; 152303/2016-2; 151473/2018-8) for scholarships. CZZ thanks CAPES (001/1700071) for scholarship. The funders had no role in study design, data collection and analysis, decision to publish, or preparation of the

manuscript.

\section{Ethical approval}

All applicable international, national, and/or institutional guidelines for the care and use of animals were followed. All procedures performed in studies involving animals were in accordance with the ethical standards of the institution or practice at which the studies were conducted (Institutional Animal Care and Use Committee from Utah State University, permit 2002 and from Universidade Vila Velha, permit 3552015). Sampling permits were issued by Sistema de Autorização e Informação em Biodiversidade (SISBIO, 28607-3; 50402; 30344; 44755; 63575).

\section{Conflict of interest}

The authors declare that they have no conflict of interest. 
833 Altmann J (1974) Observational study of behavior: sampling methods. Behav 49:227-267

834 Barrett AK, Seeley TD (2015) The declining use of animal and behaviour images in animal behavior

835 Journals. Anim Behav 103:171-177

836 Blackburn DC, Hanken J, Jenkins Jr (2008) Concealed weapons: erectile claws in African frogs. Biol Lett

$837 \quad 4: 355-357$

838 Blair AP (1947) Defensive use of parotoid secretion by Bufo marinus. Copeia 1947:137

839 Borteiro C, Rosset SD, Kolenc F, Barrasso DA, Lescano, JN, Baldo D (2018) Stereotyped defensive

840 behaviours in frogs of the genus Odontophrynus (Amphibia: Anura: Odontophrynidae). Curr Herpetol

$841 \quad 37: 172-179$

842 Boulenger GA (1902) Further notes on the African batrachians Trichobatrachus and Gampsosteonyx.

843 Proc Zool Soc Lond II:709-710

844 Brizzi R, Corti C (2007) Cutaneous antipredatory secretions and pheromones in anurans and urodeles.

845 Mar Freshw Behav Physiol 40:225-231

846 Brodie ED Jr (1977) Salamander antipredator postures. Copeia 1977:523-535

847 Brodie ED Jr, Formanowicz DR, Brodie ED III (1991) Predator avoidance and antipredator mechanisms:

848 distinct pathways to survival. Ethol Ecol Evol 3:73-77

849 Brodie ED Jr, Tumbarello MS (1978) The antipredator functions of Dendrobates auratus (Amphibia:

850 Anura: Dendrobatidae) skin secretion in regard to a snake predator (Thamnophis). J Herpetol 12:264-265

851 Brodie ED Jr, Williams CR, Tyler MJ (1998) Evolution of aposematic behavior and coloration in the

852 Australian frog genus Uperoleia. J Herpetol 32:136-139

853 Brodie ED III, Feldman CR, Hanifin CT, Motychak JE, Mulcahy DG, Williams BL, Brodie ED Jr (2005)

854 Parallel arms races between garter snakes and newts involving tetrodotoxin as the phenotypic interface of

855 coevolution. J Chem Ecol 31:343-356

856 Caro T (2014) Antipredator deception in terrestrial vertebrates. Curr Zool 60:16-25

857 Channing A, Howell K (2003) Phlyctimantis keithae (Wot-wot). Herpetol Rev 34:52-53

858 Choi I, Lee SH, Ricklefs RE (1999) Effectiveness and ecological implications of anuran defenses against 859 snake predators. Korean J Biol Sci 3:247-252 
861 Darst CR, Cummings ME, Cannatella DC (2006) A mechanism for diversity in warning signals:

862 conspicuousness versus toxicity in poison frogs. P Natl Acad Sci USA 103:5852-5857

863 Dodd CK (1976) A bibliography of anuran defensive mechanisms. Smithson Herpetol Inf Serv 37:1-10

864 Duellman WE, Trueb L (1994) Biology of amphibians. The Johns Hopkins University Press, London

865 Edmunds M (1974) Defence in animals. Longman, Essex, Harrow

866 Emerson SB, Cooper TA, Ehleringer JR (1990) Convergence in reflectance spectra among treefrogs.

867 Funct Ecol 4:47-51

868 Emerson SB, Koehl MAR (1990) The interaction of behavioral and morphological change in the

869 evolution of a novel locomotor type: "flying" frogs. Evolution 44:1931-1946

870 Endler JA (1978) A predator's view of animal color patterns. Evol Biol 11:319-364

871 Evans CM, Brodie ED Jr (1994) Adhesive strength of amphibian skin secretions. J Herpetol 28:499-502

872 Ferrante L, Sacramento M, Angulo A (2014) Defensive behaviour in Aplastodiscus leucopygius (Cruz

873 and Peixoto 1985) (Anura: Hylidae). Herpetol Notes 7:135-138

874 Ferreira RB, Faivovich J, Beard KH, Pombal J (2015) The first bromeligenous species of Dendropsophus

875 (Anura: Hylidae) from Brazil's Atlantic Forest. PLoS ONE 10:e0142893

876 Figueiredo GT, Lourenço-de-Moraes R, Neto NGP, Anjos L (2017) Ischnocnema henselii (Defensive

877 behavior). Herpetol Rev 48:163

878 Firschein L (1951) Phragmosis and the "unken reflex" in a Mexican hylid frog, Pternohyla fodiens.

879 Copeia 1951:74

880 Frost DR (2019) Amphibian species of the world: and online reference. American Museum of Natural

881 History, http://research.amnh.org/herpetology/amphibia/index.html

882 Janik VM (1999) Pitfalls in the categorization of behaviour: a comparison of dolphin whistle

883 classification methods. Anim Behav 57:133-143

884 Jared C, Antoniazzi MM, Navas CA, Katchburian E, Freymuller DV, Tambourgi DV, Rodrigues MT

885 (2005) Head co-ossification, phragmosis and defence in the casque-headed tree frog Corythomantis

886 greening. J Zool 265:1-8

887 Jared C, Mailho-Fontana PL, Antoniazzi MM, Barbaro KC, Rodrigues MT, Brodie ED Jr (2015)

888 Venomous frogs use heads as weapons. Curr Biol 25:2166-2170 

imperilment across the amphibian tree of life. Ecol Evol 2:850-858

891 Johnson JA, Brodie ED Jr (1975) The selective advantage of the defensive posture of the newt Taricha granulosa. Am Midl Nat 93:139-148

893 King G, Keohane RO, Verba S (1994) Designing social inquiry: scientific inference in qualitative research. Princeton University Press, Princeton Lenzi-Mattos R, Antoniazzi MM, Haddad CFB, Tambourgi DV, Rodrigues MT, Jared C (2005) The inguinal macroglands of the frog Physalaemus nattereri (Leptodactylidae): structure, toxic secretion and relationship with deimatic behaviour. J Zool 266:385-394 351

Lourenço-de-Moraes R (2012) Proceratophrys avelinoi, Cycloramphus acangatan. Defensive behavior. chaquensis (Anura: Leptodactylidae). Herpetol Notes 7:391-392

904 Lourenço-de-Moraes R, Ferreira RB, Fouquet A, Bastos RP (2014b) A new diminutive frog species of 905 Adelophryne (Amphibia: Anura: Eleutherodactylidae) from the Atlantic Forest, southeastern Brazil. Zootaxa 3846:348-360

907 Lourenço-de-Moraes R, Ferreira RB, Mira-Mendes CV, Zocca CZ, Medeiros T, Ruas DS, Rebouças R, 908 Toledo LF, Brodie ED Jr, Solé M (2016) Escalated antipredator mechanisms of two neotropical marsupial 909 treefrogs. J Herpetol 26:237-244

910 Lourenço-de-Moraes R, Pertel W (2011) Pseudopalodicola cf. mystacalis. Predation. Herpetol

$911 \operatorname{Rev} 42: 414$

912 Lourenço-de-Moraes R, Solé M, Toledo LF (2012) A new species of Adelophryne Hoogmoed and

913 Lescure (1984) (Amphibia: Anura: Eleutherodactylidae) from the Atlantic rainforest of southern Bahia,

914 Brazil. Zootaxa 344:59-68

915 Maddison WP, Maddison DR (2015) Mesquite: a modular system for evolutionary analysis, Version 3.04.

916 Mesquite Project Team, http://mesquiteproject.org

917 Mailho-Fontana PL, Antoniazzi MM, Toledo LF, Verdade VK, Sciani JM, Barbaro KC, Pimenta DC, 
918 Rodrigues MT, Jared C (2014) Passive and active defense in toads: the paratoid macroglands in Rhinella

919 marina and Rhaebo guttatus. J Exp Zool 321:65-77

920 Mângia S, Santana DJ (2013) Defensive behavior in Rhinella granulosa (Spix 1824) (Amphibia: Anura:

921 Bufonidae). Herpetol Notes 6:45-46

922 Marchisin A, Anderson JD (1978) Strategies employed by frogs and toads (Amphibia: Anura) to avoid

923 predation by snakes (Reptilia: Serpente). J Herpetol 12:151-155

924 McCay M (2001) Aerodynamic stability and maneuverability of the gliding frog Polypedates dennysi. J

925 Exp Biol 204:2817-2826

926 Merilaita S (2003) Visual background complexity facilitates the evolution of camouflage. Evolution

$927 \quad 57: 1248-1254$

928 Merilaita S, Lind J (2005) Background-matching and disruptive coloration, and the evolution of cryptic

929 coloration. Proc R Soc Lond B 272:665-670

930 Merilaita S, Lyytinen A, Mappes J (2001) Selection for cryptic coloration in a visually heterogeneous

931 habitat. Proc R Soc Lond B 268:1925-1929

932 Merilaita S, Tuomi J, Jormalainen V (1999) Optimisation of cryptic coloration in heterogeneous habitats.

933 Biol J Linn Soc 67:151-161

934 Miyatake T, Katayama K, Takeda Y, Nakashima A, Sugita A, Mizumoto M (2004) Is death feigning

935 adaptive? Heritable variation in fitness difference of death-feigning behaviour. Proc R Soc Lond B

$936 \quad 271: 2293-2296$

937 Mônico AT, Zocca CZ, Lourenço-de-Moraes R, Campos FS, Ferreira RB (2016) Myersiella microps

938 (Antipredator mechanisms). Herpetol Rev 47:644

939 Mukherjee S, Heithaus MR (2013) Dangerous prey and daring predators: a review. Biol Rev 88:550-563

940 Nishiumi N, Mori A (2015) Distance-dependent switching of anti-predator behavior of frogs from

941 immobility to fleeing. J Ethol 33:117-124

942 Nishiumi N, Mori A (2016) Immobile defence of a frog distracts attention of approaching predators to

943 other prey. Behaviour 153:1387-1401

944 Nystrand O, Granström A (1997) Post-dispersal predation on Pinus sylvestris seeds by Fringilla spp:

945 ground substrate affects selection for seed color. Oecologia 110:353-359

946 Perret JL (1961) La biologie d'Acanthixalus spinosus (Amphibia: Salientia). Rech Etud Camerounaises 
948 Sandoval CP (1994) The effects of the relative geographic scales of gene flow and selection on morph

949 frequencies of Timema cristinae. Evolution 48:1866-1879

950 Santos JC, Cannatella DC (2011) Phenotypic integration emerges from aposematism and scale in poison

951 frogs. P Natl Acad Sci USA 108:6175-6180

952 Sazima I (1974) Experimental predation on the leaf-frog Phyllomedusa rohdei by the water snake Liophis

953 miliaris. J Herpetol 8:376-377

954 Sazima I (1978) Convergent defensive behavior of two leaf-litter frogs of southeastern Brazil. Biotropica

$955 \quad 10: 158$

956 Sazima I, Caramaschi U (1986) Descrição de Physalaemus deimaticus sp. n., e observações sobre

957 comportamento deimatico em P. nattereri (Steindachner 1863) (Anura: Leptodactylidae). Rev Bras Biol

$958 \quad 13: 91-101$

959 Schwalm PA, Starrett PH, McDiarmid RW (1977) Infrared reflectance in leaf-sitting Neotropical frogs.

960 Science 196:1225-1227

961 Shine RG (1993) Sexual dimorphism in snakes. In: Seigel RA, Collins JT (eds) Ecology and Behavior.

962 McGraw-Hill, New York, pp 49-86

963 Siddiqi A, Cronin TW, Loew ER, Vorobyev M, Summers K (2004) Interspecific and intraspecific views

964 of color signals in the strawberry poison frog Dendrobates pumilio. J Exp Biol 207:2471-2485

965 Smith BPC, Williams CR, Tyler MJ, Williams BD (2004) A survey of frog odorous secretions, their

966 possible functions and phylogenetic significance. Appl Herpetol 2:47-82

967 Thayer GH (1909) Concealing-coloration in the animal kingdom. Macmillan, New York

968 Toledo LF (1995) Predation of juvenile and adult anurans by invertebrates: current knowledge and

969 perspectives. Herpetol Rev 36:395-400

970 Toledo LF, Becker CG, Haddad CFB, Zamudio KR (2014) Rarity as an indicator of endangerment in

971 Neotropical frogs. Biol Conserv 179:54-62

972 Toledo LF, Haddad CFB (2009) Colors and some morphological traits as defensive mechanisms in

973 anurans. Int J Zool 2009:910892

974 Toledo LF, Martins IA, Bruschi DP, Passos MA, Alexandre C, Haddad CFB (2015) The anuran calling

975 repertoire in the light of social context. Acta Ethol 18:87-99 
976 Toledo LF, Sazima I, Haddad CFB (2010) Is it all death feigning? Case in anurans. J Nat Hist 44:1979-

9771988

978 Toledo LF, Sazima I, Haddad CFB (2011) Behavioural defences of anurans: an overview. Ethol Ecol

979 Evol 23:1-25

980 Toledo RC, Jared C (1995) Cutaneous granular glands and amphibian venoms. Comp Biochem Physiol

$981 \quad 111: 1-29$

982 Turner GC (1961) Bacilluria in pregnancy. Lancet 2:1062-1064.

983 Webster RJ, Callahan A, Godin J-GJ, Sherratt TN (2011) Camouflage behaviour and body orientation on

984 backgrounds containing directional patterning. In: Wells KD (ed) Animal camouflage: mechanisms and

985 function. Cambridge University Press, Cambridge, pp 101-117

986 Wells KD (2007) The ecology and behavior of amphibians. University of Chicago Press, Chicago

987 Williams CR, Brodie ED Jr, Tyler MJ, Walker SJ (2000) Antipredator mechanisms of Australian frogs. J

988 Herpetol 34:431-443

989 Zocca CZ, Ferreira FCL, Ferreira RB (2014) Observações sobre história natural de Zachaenus carvalhoi

990 Izecksohn 1983"1982" (Amphibia: Anura: Cycloramphidae). Bol Mus Biol Mello Leitão 34:63-74

991 Zug GR, Vitt LJ, Caldwell JP (2001) Herpetology: an introductory biology of amphibians and reptiles.

992 Academic Press, New York 
Table 1 Classification of antipredator mechanisms of post-metamorphic anurans

\begin{tabular}{lll}
\hline Phases & Antipredator mechanisms & Variations \\
\hline Avoid detection & & \\
& $\begin{array}{l}\text { 1. Camouflage } \\
\text { 2. Immobility }\end{array}$ & $\begin{array}{l}\text { a. Background matching } \\
\text { b. Disruptive }\end{array}$ \\
& 3. Interrupt calling & - \\
\hline
\end{tabular}

\section{Prevent Attack}
4. Aposematism
a. Exposed
b. Hidden

5. Charge

6. Posture
a. Body elevation
b. Body inflation
c. Contraction
d. Gland exposure
e. Limbs interweave
f. Mouth gape
g. Rear elevation
h. Stretching limbs
i. Death feigning
j. Unken reflex

7. Escape
a. Climb
b. Glide
c. Hide
d. Jump away
e. Roll
f. Swim

8. Warning sound

\section{Counterattack}

9. Cloacal discharge

10. Secretion
a. Adhesive
b. Odoriferous
c. Slippery
d. Poisonous

11. Aggression
a. Bite
b. Headbutt
c. Kick
d. Puncture

12. Distress call 
997 Fig. 1 Number of publications of antipredator mechanisms of anurans over the years

998

Fig. 2 Reconstruction of ancestral state of the 12 antipredator mechanisms in Anura. Black branches= presence of the mechanism, and white branches= absence of the mechanism. a) Camouflage; b) Immobility; c) Interrupt calling; d) Aposematism; e) Charge; f) Posture; g) Escape; h) Warning sound; i) Cloacal discharge; j) Secretion; k) Aggression; 1) Distress call; m) Tree of life (families); (*) outgroup.

Fig. 3 Background matching: a) Bokermannohyla alvarengai (Hylidae) resemble lichen-covered rock with flange and a pale fringe that breaks up the shadow; b) Dendrophryniscus brevipollicatus (Bufonidae) has brownish dominant dorsal color to resemble leaf litter; c) Hyalinobatrachium cappelei (Centrolenidae) has partial transparent venter resembling green leaf; d) Odontophrynus americanus (Odontophrynidae) has a variety of warts and tubercles to resemble stones, bird dropping, or fallen leaves. Photos: F. Leal (a), T. Silva-Soares (b), R. Oliveira (c), and RL-d-M (d)

1010

Fig. 4 Disruptive coloration: a) Boana cipoensis (Hylidae); b) Dendropsophus elegans (Hylidae) have contrasting markings that break up the appearance of body form. Photos: F. Leal (a) and RL-d-M (b)

Fig. 5 Immobility: a) Haddadus binotatus (Craugastoridae) alert and prepared to jump away; b) Thoropa miliaris (Cycloramphidae) flat against the ground to use the cryptic dorsal coloration. Photos: F.S. Campos (a) and T. Silva-Soares (b)

Fig. 6 Aposematism: a) Brachycephalus alipioi (Brachycephalidae) has aposematic coloration over the entire body (exposed aposematism); b) Uperoleia lithomoda (Myobatrachidae) showing four red eyespots; c) Edalorhina perezi (Leptodactylidae) showing a pair of black eyespots; d) Phyllomedusa burmeisteri (Hylidae) showing the bright yellow color on the thighs (hidden aposematism). Photos: J.L. 
Fig. 7 Posture of body elevation: a) Rhaebo gutattus (Bufonidae) extending the front limbs (partial body

1025

1026

1027

1028

1029

1030

1031

1032

1033

1034

1035

1036

1037

1038

1039

1040

1041

1042

1043

1044

1045

1046

1047

1048

1049

1050

1051

1052 elevation) and b) Rana areolata (Ranidae) extending the four limbs (full body elevation). Photos: T. Silva-Soares (a) and EDB (b)

Fig. 8 Posture of body inflation: a) Dermatonotus muelleri (Microhylidae) and b) Dyscophus antongilii (Microhylidae) inflating the body. Photos: J.F.R. Tonini (a) and EDB (b)

Fig. 9 Posture of contraction: Itapotihyla langsdorffii (Hylidae) contracting with: a) the dorsum and b) venter pointing to the substrate. Photo: RL-d-M (a) and CZ (b)

Fig. 10 Posture of gland exposure: a) Proceratophrys paviotii (Odontophrynidae) directing the parotoid glands toward the predator and b) Aparasphenodon brunoi (Hylidae) exposing the ossified head with glands and obstructing the bromeliad. Photos: RBF (a) and T. Silva-Soares (b)

Fig. 11 Posture of limbs interweave: a) Leptodactylus chaquensis (Leptodactylidae) and b) Hylomantis aspera (Phyllomedusidae) spreading skin secretion over the body. Photo: RL-d-M (a) and M. Gally (b)

Fig. 12 Posture of mouth gape: a) Lepidobatrachus laevis (Ceratophryidae) and b) Ceratophrys ornata (Ceratophryidae) opening the mouth toward the predator. Photo: EDB $(a, b)$

Fig. 13 Posture of rear elevation: Physalaemus nattereri (Leiuperidae): a) partial rear elevation and b) full rear elevation. Photo: EDB $(\mathrm{a}, \mathrm{b})$

Fig. 14 Posture of stretching limbs: a) Stereocyclops incrassatus (Microhylidae) and b) Proceratophrys schirchi (Odontophrynidae) stretching the limbs. Photos: J.F.R. Tonini (a) and A.T. Mônico (b)

Fig. 15 Posture of death feigning: a) Pristimantis vinhai (Brachycephalidae) and b) Ischnocnema erythromera (Brachycephalidae) have the fore and hind limbs loose and laying the dorsum on the substrate. Photos: RL-d-M (a, b) 
1054 Fig. 16 Posture of unken reflex: a) Dendrophryniscus boulengeri (Bufonidae) displaying the reddish 1055 palms of the front limbs (partial unken reflex) and b) Bombina variegata (Bombinatoridae) showing 1056 aposematic venter and palms of the four limbs (full unken reflex). Photos: RL-d-M (a) and EDB (b)

1057

1058

Fig. 17 Escape: a) Rhacophorus sp. (Rhacophoridae) that jumps from a vertical substrate to glide until 1059 reaching another substrate (glide) and b) Oreophrynella nigra (Bufonidae) rolls down sloped terrain. 1060 Photos: P. Gambale (a) and C. Brooke (b)

1062 Fig. 18 Aggression: a) Gastrotheca megacephala (Hemiphractidae) biting the predator (bite) and b) 1063 Leptodactylus pentadactylus (Leptodactylidae) has spines (red arrow) used to puncture the predator (puncture). Photo: RBF (a) and EDB (b) 